\title{
Use of SYBR Green I for rapid epifluorescence counts of marine viruses and bacteria
}

\author{
Rachel T. Noble*, Jed A. Fuhrman \\ University of Southern California, Department of Biological Sciences, AHF 107, University Park, Los Angeles, \\ California 90089-0371, USA
}

\begin{abstract}
A new nucleic acid stain, SYBR Green I, can be used for the rapid and accurate determination of viral and bacterial abundances in diverse marine samples. We tested this stain with formalinpreserved samples of coastal water and also from depth profiles (to $800 \mathrm{~m}$ ) from sites 19 and $190 \mathrm{~km}$ offshore, by filtering a few $\mathrm{ml}$ onto $0.02 \mu \mathrm{m}$ pore-size filters and staining for $15 \mathrm{~min}$. Comparison of bacterial counts to those made with acridine orange (AO) and virus counts with those made by transmission electron microscopy (TEM) showed very strong correlations. Bacterial counts with AO and SYBR Green 1 were indistinguishable and almost perfectly correlated $\left[\mathrm{r}^{2}=0.99\right)$. Virus counts ranged widely, from 0.03 to $15 \times 10^{7}$ virus $\mathrm{ml}^{-1}$. Virus counts by SYBR Green I were on the average higher than those made by TEM, and a SYBR Green I versus TEM plot yielded a regression slope of 1.28 . The correlation between the two was very high with an $\mathrm{r}^{2}$ value of 0.98 . The precision of the SYBR Green I method was the same as that for TEM, with coefficients of variation of $2.9 \%$. SYBR Green I stained viruses and bacteria are intensely stained and easy to distinguish from other particles with both older and newer generation epifluorescence microscopes. Detritus is generally not stained, unlike when the alternative dye YoPro I is used, so this approach may be suitable for sediments. SYBR Green I stained samples need no desalting or heating, can be fixed with formalin prior to filtration, the optimal staining time is $15 \mathrm{~min}$ (resulting in a total preparation time of less than $25 \mathrm{~min}$ ), and counts can be easily performed at sea immediately after sampling. This method may facilitate incorporation of viral research into most aquatic microbiology laboratories.
\end{abstract}

KEY WORDS; Virus · Epifluorescence - SYBR Green I - Marine ecology

\section{INTRODUCTION}

Viruses are now known to be an important component of the marine microbial food web (Bergh et al. 1989, Bratbak et al. 1990, Proctor \& Fuhrman 1990, Fuhrman \& Suttle 1993, Fuhrman \& Noble 1995) There are few studies of total virus distributions (Hara et al. 1991, Wommack et al. 1992, Cochlan et al. 1993), and even fewer that focus upon offshore acean waters. Current research in this area requires the ability to count viruses directly. In the past, preparation of samples for counting by transmission electron microscopy (TEM) has been the standard method (Bergh et al. 1989, Børsheim et al. 1990). However, this method

\footnotetext{
•E-mail: noble@usc.edu
}

involves intensive, time-consuming preparation, and expensive ultracentrifugation and electron microscopy equipment not available to many research laboratories. In addition, electron microscopy techniques cannot be performed in the field. In recent years, DAPI (4',6-diamidino-2-phenylindole) has evolved as a stain useful for enumeration of virus particles by epifluorescence microscopy (Suttle et al. 1990, Hara et al. 1991, Proctor \& Fuhrman 1992). However, DAPI is not sufficiently bright to be used with direct visual observation on many microscopes, and methods like photomicrography or image intensification have been used (Hara et al. 1991, Fuhrman et al. 1993). Newer microscopes may allow direct visual counts with this stain (Weinbauer \& Suttle 1997). Many labs do not possess such microscopes and would prefer to have a brighter stain available. One such stain, Yo-Pro I, has been sug- 
gested for such studies (Hennes \& Suttle 1995, Weinbauer \& Suttle 1997). The stain intensity is quite bright, but the initial report indicated incompatibility with regularly used aldehydes as fixatives, it requires extra dilution and rinsing steps to remove salts, and the optimal staining time is reported to be $2 \mathrm{~d}$. A proposed improvement upon this method, by Xenopolous \& Bird (1997), involves the microwaving of Yo-Pro I stained samples for a few minutes to allow dye penetration. These authors report fixation with aldehydes is possible, but the suggested protocol involves several extra steps in treatment of the sample, and few marine samples have been tested.

Here, we present a new stain for enumeration of virus particles, SYBR Green I (Molecular Probes, Inc.; molecular formula is proprietary), referred to throughout the rest of this article as SYBR I. Reported previously for use with flow cytometry (Marie et al. 1997), SYBR I appears to be a viable tool for enumerating viruses and bacteria in seawater. This stain, which yields virus counts comparable to TEM in a broad variety of samples, has the advantages of being usable in conjunction with seawater and ordinarily used fixatives, and its staining time is only $15 \mathrm{~min}$. In addition to the methodological advantages that SYBR I confers, it is inexpensive and its manufacturer claims it to be much less carcinogenic than other typical nucleic acid stains.

\section{MATERIALS AND METHODS}

Sample collection. Water samples were collected by 101 Niskin bottles mounted on a Seabird rosette (on board ship), or by bucket (from Santa Monica Pier, CA, USA, and Denmark) and transferred into acid-rinsed $50 \mathrm{ml}$ polypropylene tubes. Samples were taken from a range of marine environments (eutrophic to oligotrophic deep water): Santa Monica Pier surface water, 1 May 1997 (34 05' $\left.\mathrm{N}, 118^{\circ} 30^{\prime} \mathrm{W}\right), 19 \mathrm{~km}$ offshore in San Pedro Channel, midway between Long Beach,

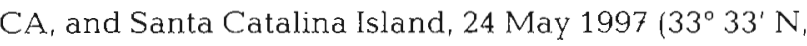
$118^{\circ} 24^{\prime} \mathrm{W}$, depth profile A, surface to $800 \mathrm{~m}$ ), an open ocean site ca $190 \mathrm{~km}$ offshore, directly west of Del Mar, CA, 25 May 1997 (32 $53^{\prime}$ N, $120^{\circ} 44^{\prime}$ W, depth profile $B$, surface $10750 \mathrm{~m}$ ), and a freshwater pond sample from Hellebaek, Denmark, 14 April 1997, and were immediately fixed with $0.02 \mu \mathrm{m}$ filtered $2 \%$ formalin (final concentration) and stored at $4{ }^{\circ} \mathrm{C}$.

Virus and bacterial counts - tranmission electron microscopy (TEM). Viruses and bacteria were counted by ultracentrifugation $\left(120000 \times \mathrm{g}, 3 \mathrm{~h}, 20^{\circ} \mathrm{C}\right)$ of $4 \mathrm{ml}$ seawater samples ( $2 \%$ formalin-preserved) onto carbon stabilized Formvar-coated 200-mesh copper grids (Ted Pella, Inc.) (Børsheim et al. 1990, Cochlan et al. 1993). For water samples from below $100 \mathrm{~m}, 4 \mathrm{ml}$ sam- ples were spun 2 to 4 consecutive times (by removing supernatant fluid after the first spin and adding $4 \mathrm{ml}$ fresh sample) in order to sediment enough particles onto the grids for counting. Grids were then stained with $1 \%(\mathrm{w} / \mathrm{v})$ uranyl acetate for $30 \mathrm{~s}$. Viruses and bacteria were enumerated on a JEOL 100 CXII TEM. Taper corrections were implemented into the final calculations (Mathews \& Buthala 1970, Suttle 1993) Viruses were counted at $27000 \times$ and bacteria at $10000 \times$ and $8000 \times(80 \mathrm{keV})$.

Acridine orange direct counts (AODC). Counts of bacteria were performed from $2 \%$ formalin-preserved samples (Hobbie et al. 1977). Briefly, a few $\mathrm{ml}$ of seawater was stained with acridine orange $(0.1 \% \mathrm{w} / \mathrm{v})$ filtered at $20 \mathrm{kPa}$ onto (replicate) $0.2 \mu \mathrm{m}$ pore size polycarbonate (Nuclepore) filters, and counted by epifluorescence microscopy under blue excitation with an Olympus Vanox or BH2 microscope.

Epifluorescence microscopy with SYBR I. SYBR I has a proprietary formula and its manufacturer (Molecular Probes, Inc., Eugene, OR, USA) does not report its molecular weight or concentration. The SYBR I used for this study (Lot \#3142-1), when diluted 1000-fold in sterile water, had an $\mathrm{OD}_{494}$ (optical density) of 0.42 .

When possible, preparation was done under subdued light. SYBR I was diluted 1:10 of the supplied concentration with $0.02 \mu \mathrm{m}$ filtered deionized water. For each new filter, $2.5 \mathrm{\mu l}$ of the $10 \%$ SYBR I working solution was added to a $97.5 \mu \mathrm{l}$ drop of $0.02 \mu \mathrm{m}$ filtered, sterile deionized water on the bottom of a clean plastic Petri dish (final dilution $2.5 \times 10^{-3}$ ). Using a Millipore $25 \mathrm{~mm}$ glass filter holder, a fixed sample of 1 to $5 \mathrm{ml}$ was filtered through a $0.02 \mu \mathrm{m}$ pore size $\mathrm{Al}_{2} \mathrm{O}_{3}$ Anodisc 25 membrane filter (Whatman), backed by a $0.8 \mu \mathrm{m}$ cellulose mixed ester membrane (Millipore type AA) at approximately $20 \mathrm{kPa}$ vacuum. The Anodisc membrane was filtered to dryness, removed with forceps with the vacuum still on, and laid sample side up on the drop of the staining solution for $15 \mathrm{~min}$ in the dark. After the staining period, the filter was picked up and any remaining moisture was then carefully wicked away by touching the back side of the membrane to a Kimwipe (any droplets on the top plastic rim of the filter were also blotted). The Anodisc filter was mounted on a glass slide with a drop of $50 \%$ glycerol, $50 \%$ phosphate buffered saline (PBS, $0.05 \mathrm{M} \mathrm{Na}_{2} \mathrm{HPO}_{4}, 0.85 \% \mathrm{NaCl}$, pH 7.5) with $0.1 \%$ p-phenylenediamine (Sigma Chem. Co., made fresh daily from frozen $10 \%$ aqueous stock) on a $25 \mathrm{~mm}$ square cover slip, then immersion oil was placed above the cover slip. This mountant minimized fading and was preferred to other mountants. Mountants that were acceptable (in decreasing order of preference) included $0.5 \%$ ascorbic acid in $50 \%$ glycerol $50 \%$ PBS, SlowFade (anti-fade product sold by Molecular Probes, Inc.) and pure glycerol. Slides were usually 
counted immediately but could be stored frozen for at least a few weeks. For each filter, 10 to 20 fields were selected randomly and a total of $>200$ viruses and $>200$ bacteria were counted on an Olympus Vanox or BH2 epifluorescence microscope with $100 \times$ objectives (Achromat, S Plan Achromat, or D Plan Apochromat UV), under blue excitation. Virus particles were distinctly shaped 'pinpricks' and fluoresced bright green, and bacterial cells could easily be distinguished from viruses because of their relative size and brightness.

Photomicrography was done from a Santa Monica Bay seawater sample, photographed with the Vanox microscope and D Plan Apochromat UV lens on Kodak Ektachrome film (400 ASA), with a 30 s exposure.

\section{RESULTS}

A seawater sample collected from Santa Monica Pier and stained with SYBR I shows that the bacteria are intensely stained, virus-like particles are brightly stained and countable, and only the nuclei of protists such as diatoms are stained, with autofluorescence readily showing chloroplasts (Fig. 1). Detritus is not significantly stained by SYBR I in our observation.

In coastal samples collected between 31 October 1996 and 15 January 1997, we found that SYBR I bacteria counts were essentially identical to acridine orange counts, with SYBR I/AODC of $103 \pm 4.2 \%$ (mean $\pm \mathrm{SD}, \mathrm{n}=20$ ) and an $\mathrm{r}^{2}$ of 0.99 . No further comparison was performed.

Virus counts by both SYBR I and TEM showed very similar patterns from both depth profiles. Virus abundances generally decreased with depth (Fig. 2). In both profiles, a dramatic decrease in viral numbers occurred at about $50 \mathrm{~m}$, the lower part of the euphotic zone (Fig. 2). The average decrease in total virus abundance throughout the water column was matched by a similar decrease in bacterial numbers. At the open ocean site, the maximum virus abundance was observed at $25 \mathrm{~m}$, rather than at the surface (Fig. 2B). Bacterial counts as determined by SYBR I generally decreased with depth

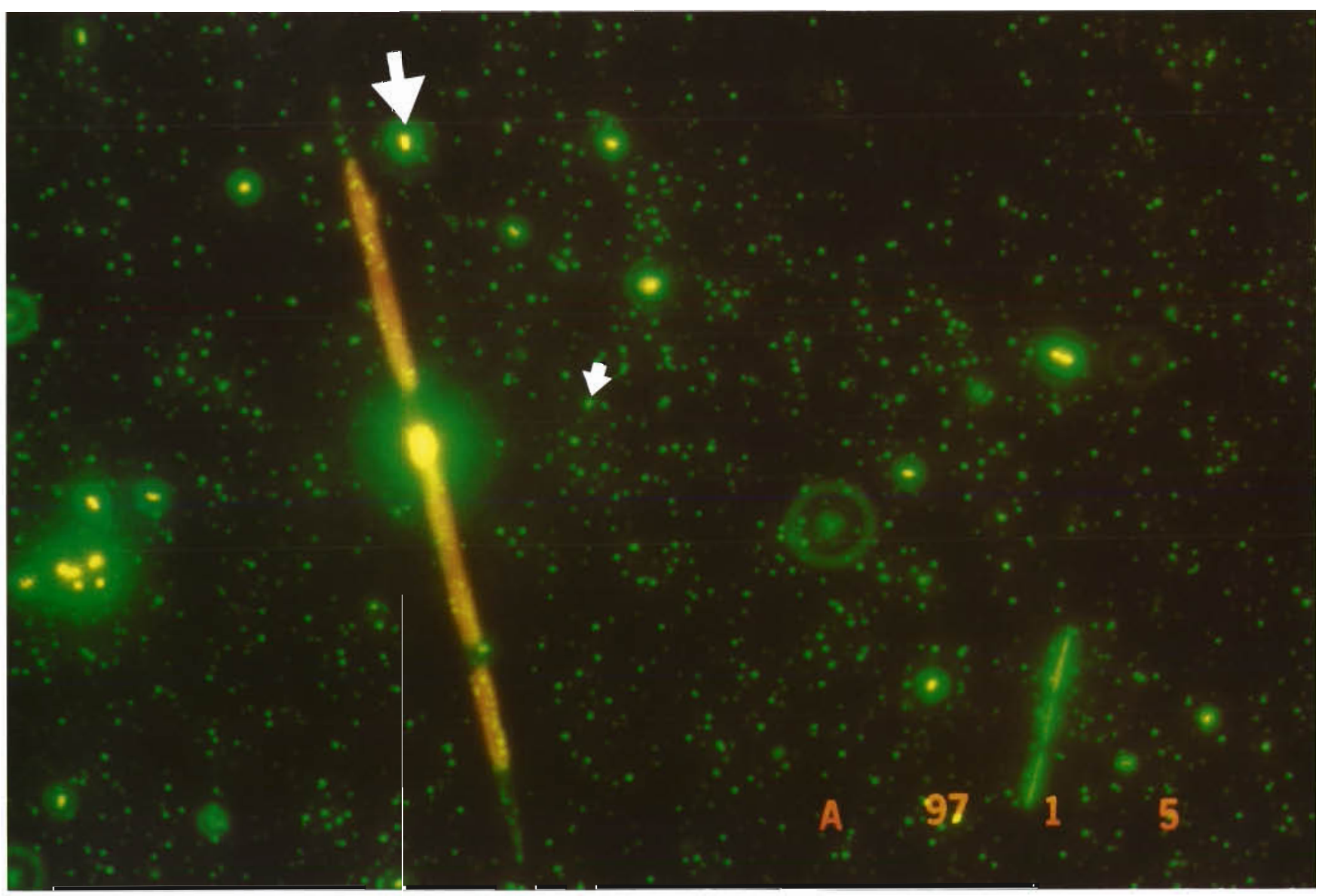

Fig. 1. SYBR Green I stained sample from Santa Monica Bay, CA, USA, 1 May 1997. The larger bright green particles are counted as bacteria (large arrow) and the smaller, more numerous ones are counted as viruses (small arrow). The nucleus of the large pennate diatom $(80 \mu \mathrm{m}$ long) is brightly stained, with red autofluorescence indicating chloroplasts 

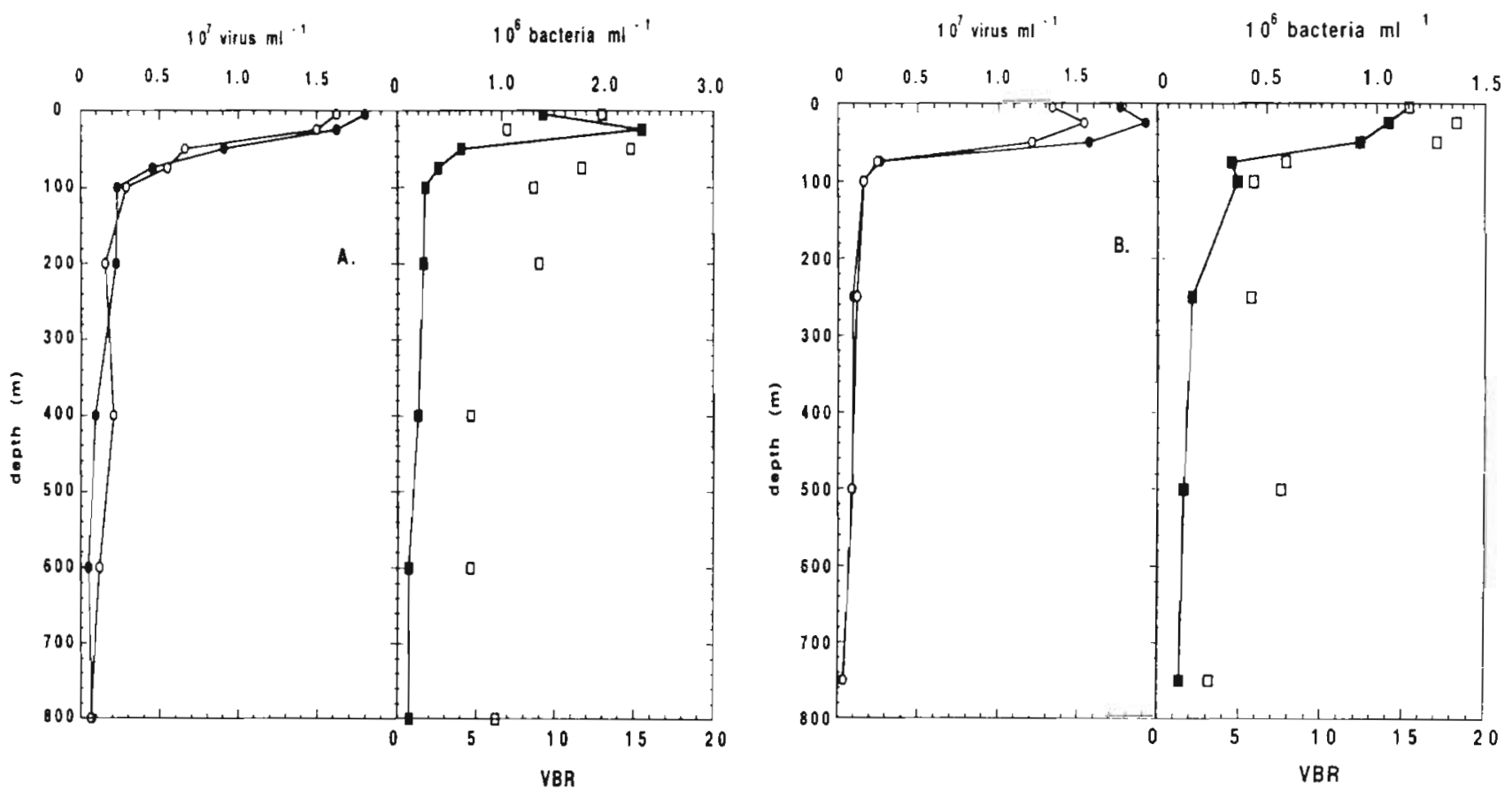

Fig. 2. (A) Depth profile A (surface to $800 \mathrm{~m}$ ). Seawater collected from site $19 \mathrm{~km}$ offshore on 24 May 1997 (B) Depth profile B (surface to $750 \mathrm{~m}$ ). Seawater collected from open ocean site $190 \mathrm{~km}$ offshore on 25 May 1997. (1) Virus counts with SYBR Green I; (0) virus counts done by transmission electron microscopy (TEM). (1) Bacterial counts with SYBR Green I. () Virus:bacteria ratio (VBR)

in both depth profiles, although at the site $19 \mathrm{~km}$ offshore there was a subsurface maximum of bacterial abundance at $25 \mathrm{~m}$ (Fig. 2A). The virus:bacteria ratio (VBR) in both depth profiles was $14.2 \pm 3.6$ (pooled average $\pm \mathrm{SD}$ ) within the euphotic zone. However, below the euphotic zone, the VBR dropped to about

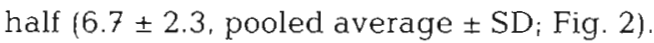

A direct comparison of the 18 seawater samples shows that SYBR I and TEM-based virus counts are highly correlated $\left(r^{2}=0.98, n=18, p<0.001\right)$ (Fig. 3). There was a tendency for the SYBR I counts to be higher, indicated by the slope of the linear regression being 1.28 (forced through zero at intercept) (Fig. 3). Scatter was relatively high at low abundances, probably because when viral abundances are very low as in deep waters, it is difficult to prepare TEM samples due to an increase in the number of ultracentrifugation spins necessary to sediment enough particles onto the grids for counting. The average coefficient of variation for the 2 types of estimates was the same for both TEM and SYBR I at $2.9 \%$. A single seawater sample from surface waters of Santa Monica Bay collected during a 'red tide' and aged 2 wk was used to provide a high virus abundance comparison of counts by TEM and by SYBR I: counts were $1.53 \pm 0.05 \times 10^{8}$ virus $\mathrm{ml}^{-1}$ (mean $\pm \mathrm{SD}, \mathrm{n}=2$ ) by SYBR I and $1.18 \pm 0.01 \times 10^{8}$ virus $\mathrm{ml}^{-1}$ by TEM. In freshwater samples of pondwater from
Denmark in April 1997, virus and bacterial counts were $2.2 \pm 0.02 \times 10^{7}$ and $4.4 \pm 0.04 \times 10^{6} \mathrm{ml}^{-1}(\mathrm{n}=4)$, respectively, although not compared to TEM. The viruses and bacteria appeared to be even more intensely stained than those from seawater.

\section{DISCUSSION}

Estimates of virus and bacterial abundances for both depth profiles are consistent with other reported values in similar marine environments (Bergh et al. 1989, Børsheim et al. 1990, Bratbak et al. 1990, Proctor \& Fuhrman 1990, Cochlan et al. 1993, Hennes \& Suttle 1995). Even though the 2 depth profiles were ca $175 \mathrm{~km}$ apart, their patterns of viral and bacterial abundances were very similar The VBR was similar to average values published by Paul et al. (1991) and Cochlan et al. (1993). The VBR was greater than 10 within the euphotic zone, and was much reduced at lower viral and bacterial densities.

In the comparison of methods, virus abundances as determined by SYBR I were highly correlated to, yet were about $28 \%$ higher than, those by TEM. In recent studies by Hennes \& Suttle (1995) and Weinbauer \& Suttle (1997), Yo-Pro I based virus counts were found to average about 2.3 and 1.5 times higher than counts 


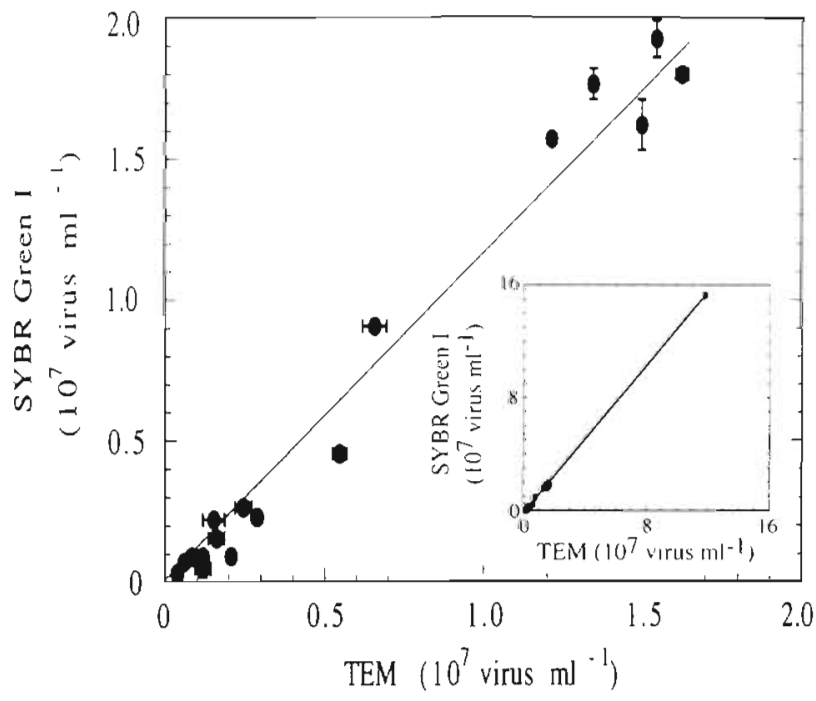

Fig. 3. Comparison of virus counts using SYBR Green I and transmission electron microscropy (TEM) for a diverse set of marine samples. Error bars indicate the standard deviation of duplicate samples; where they are not seen, the standard deviation was less than the size of the symbol. Line indicates linear regression (forced through zero). Inset figure is the same, but also includes a high abundance coastal seawater sample

by TEM, respectively, a wide range. In this study, SYBR I based virus counts were found to be about 1.3 times higher than those by TEM. It is possible that TEM based virus counts underestimate viral abundance as viruses could be lost when uranyl acetate is wicked away from the grids and viruses may be obscured by other larger, darkly stained particles on the grids. Also, filamentous viruses which would be countable with SYBR I might not be recognizable by TEM. At lower viral densities, TEM counts were generally similar to those by SYBR I, and at higher viral densities the TEM counts were clearly lower than those for SYBR I (Figs. 2 \& 3). This trend is also consistent with work published by both Hennes \& Suttle (1995) and Weinbauer \& Suttle (1997) when comparing Yo-Pro I to TEM. Both of these studies have also made some comparisons with DAPI, an alternative stain for epifluorescence microscopy. However, DAPI is relatively dim, and requires high quality optics for quantitative visualization of viruses. In contrast, viruses and bacteria stained with SYBR I are brightly stained, and can be easily distinguished (Fig. 1). An additional problem addressed by Hennes \& Suttle (1995) is the incompatibility of Yo-Pro I with sea salts as well as regularly used aldehydes such as formalin. A recent study (Xenopolous \& Bird 1997) has proposed an improvement upon the method by Hennes \& Suttle (1995) which involves microwaving the sample to reduce the necessary penetration time of the viruses with Yo-Pro I to minutes as opposed to $2 \mathrm{~d}$. This proposed improvement is reported to circumvent the incompatibility with aldehydes, but it still requires rinsing and additional steps of heating and cooling, and has not been well tested with marine samples. The ability of SYBR I to stain virus and bacterial particles is apparently not inhibited by the use of such fixatives, and the staining period is short $(15 \mathrm{~min})$ and requires no additional steps or equipment. Also, SYBR I is reported to stain both RNA and DNA. Even though RNA viruses are likely to make up only a minor fraction of the total pool of viruses based on information from surveys such as that by Frank \& Moebus (1987), the total virus abundance may be determined with this stain. In the process of method optimization, one early problem was fading of the epifluorescence signal within about $30 \mathrm{~s}$ which occurred when a more dilute concentration of SYBR I $\left(1 \times 10^{-4}\right)$ was used (in conjunction with the Molecular Probes, Inc, anti-fade product, SlowFade). Subsequently, we have found that our recommended concentration of SYBR I $\left(2.5 \times 10^{-3}\right.$ dilution $)$ yields brighter and more stably fluorescent viruses and that fading of the samples is best retarded with the use of a glycerol/PBS/phenylenediamine mixture.

It has been suggested (Stockner et al. 1990) that a portion of the heterotrophic marine bacterial population may be uncounted because they pass through a $0.2 \mu \mathrm{m}$ pore size filter, the traditionally used type for routine bacterial counts. The use of the $0.02 \mu \mathrm{m}$ pore size filters will prevent the loss of any very small bacteria. We find that it is relatively easy to distinguish between small marine bacteria and viruses, as indicated by the agreements between acridine orange and SYBR I for bacteria and TEM and SYBR I for viruses (Fig. 2). Note that even if all of the small bacteria $(<0.3 \mu \mathrm{m})$ were counted as viruses, it would not significantly affect the total virus counts because there are proportionally so many more viruses than small bacteria.

Based on our results, we recommend the use of SYBR I nucleic acid stain in conjunction with $0.02 \mu \mathrm{m}$ pore size Anopore filters for routine viral and bacterial abundance estimates from seawater. In addition, we see no reason why it should not work with freshwater samples. Furthermore, the observation that detritus is not stained suggests that this approach may be suitable for sediment studies. Recently, it has been quite difficult to incorporate viruses and virus mediated processes into research in aquatic food webs. Here we present a method which allows reasonably equipped microbiology laboratories to perform quick and simple enumerations of virus particles in natural samples. Virus counts with SYBR I can be performed easily in the lab or on board ship and can help elucidate the roles of viruses in aquatic systems. 
Acknowledgements. We thank Dr Daniel Vaulot for the discussion of the use of SYBR Green I for flow cytometry, Mathias Middelboe for freshwater sample collection in Denmark, the crew of the RV 'Point Sur' and C. Ouverney, J. Griffith, $\mathrm{T}$ Luu, A. Perdon, and C. Blake for assistance in collection of seawater samples, and $\mathrm{M}$. Weinbauer for useful comments on the use of SYBR Green I for sediment work. This research was supported by NSF Grants \#OCE-9218234 and \#OCE9634028, the Villefranche Workshop and the EEC contract Medea, MAS2-CT95-0016. R.T.N. was also funded by USC Sea Grant and by the ARCS Foundation.

\section{LITERATURE CITED}

Bergh O, Børsheim KY, Bratbak G, Heldal M (1989) High abundance of viruses found in aquatic environments. Nature 340:467-468

Børsheim KY, Bratbak G, Heldal M (1990) Enumeration and biomass estimation of planktonic bacteria and viruses by transmission electron microscopy. Appl Environ Microbiol 56:352-356

Bratbak G, Heldal M, Norland S, Thingstad TF (1990) Viruses as partners in spring bloom microbial trophodynamics. Appl Environ Microbiol 56:1400-1405

Cochlan WP, Wikner J, Steward GF, Smith DC, Azam F (1993) Spatial distribution of viruses, bacteria and chlorophyll a in neritic, oceanic and estuarine environments. Mar Ecol Prog Ser 92:77-87

Frank H, Moebus K (1987) An electron microscopic study of bacteriophages from marine waters. Helgol Meeresunters 41:385-414

Fuhrman JA, Noble RT (1995) Viruses and protists cause similar bacterial mortality in coastal seawater. Limnol Oceanogr 40(7):1236-1242

Fuhrman JA, Suttle CA (1993) Viruses in marine planktonic systems. Oceanography 6:51-63

Fuhrman JA, Wilcox RM, Noble RT, Law NC (1993) Viruses in marine food webs. In: Guerrero R, Pedrós-Alió C (eds) Trends in microbial ecology. Spanish Society for Microbiology, Barcelona, p 295-298

Hara S, Terauchi K, Koike I (1991) Abundance of viruses in marine waters: assessment by epifluorescence and trans-

Editorial responsibility: Farooq Azam,

La Jolla, California, USA mission electron microscopy. Appl Environ Microbiol 57(9): $2731-2734$

Hennes KP, Suttle CA (1995) Direct counts of viruses in natural waters and laboratory cultures by epifluorescence microscopy. Limnol Oceanogr 40(6): 1050-1055

Hobbie JE, Daley RJ, Jasper S (1977) Use of Nuclepore filters for counting bacteria by fluorescence microscopy. Appl Environ Microbiol 33:1225-1228

Marie D, Partensky F, Jacquet S, Vaulot D (1997) Enumeration and cell-cycle analysis of natural populations of marine picoplankton by flow cytometry using the nucleic-acid stain SYBR green I. Appl Environ Microbiol 63(1):186-193

Mathews J, Buthala DA (1970) Centrifugal sedimentation of virus particles for electron microscope counting. J Virol 5(5):598-603

Paul JH, Jiang SC, Rose JB (1991) Concentration of viruses and dissolved DNA from aquatic environments by vortex flow filtration. Appl Environ Microbiol 57(8):2197-2204

Proctor LM, Fuhrman JA (1990) Viral mortality of marine bacteria and cyanobacteria. Nature 343:60-62

Proctor LM, Fuhrman JA (1992) Mortality of marine bacteria in response to enrichments of the virus size fraction from seawater. Mar Ecol Prog Ser 87:283-293

Stockner JG, Klut ME, Cochlan WP (1990) Leaky filters: a warning to aquatic ecologists. Can J Fish Aquat Sci 47 $16-23$

Suttle CA (1993) Enumeration and isolation of marine viruses. In: Kemp PF, Sherr BF, Sherr EB, Cole JJ (eds) Current methods in aquatic microbial ecology. Lewis Publishing, Boca Raton, p 121-134

Suttle CA, Chan AM, Cottrell MT (1990) Infection of phytoplankton by viruses and reduction of primary productivity. Nature 387:467-469

Weinbauer MG, Suttle CA (1997) Comparison of epifluorescence and transmission electron microscopy for counting viruses in natural marine waters. Aquat Microb Ecol 13: 225-232

Wommack KE, Hill RT, Kessel M, Russek-Cohen E, Colwell RR (1992) Distribution of viruses in Chesapeake Bay. Appl Environ Microbiol 58:2965-2970

Xenopolous MA, Bird DF (1997) Virus à la sauce Yo-Pro Microwave enhanced staining for counting viruses by epifluorescence microscopy. Limnol Oceanogr 42(7)

Submitted: July 18, 1997; Accepted: September 9, 1997

Proofs received from author(s): November 21, 1997 